\title{
MINORITY SHAREHOLDERS' PROTECTION IN THE INDONESIAN CAPITAL MARKET
}

\author{
Apri Sya'bani *
}

\begin{abstract}
This paper explores the regulatory reform in Indonesia corporate governance along with capital market regulatory framework which has continuously been conducted in response to enhance minority shareholders' protection and the implementation of corporate governance in public listed companies, particularly in protecting minority shareholder right through three short cases studies. The three cases analysed in this paper show that the implementation of corporate governance in public listed companies is still weak, resulting from the lack of awareness of how to implement corporate governance by the public listed companies, the opportunistic behaviour of public listed companies using loopholes in the regulations to the weaknesses in the enforcement of capital markets law.
\end{abstract}

Keywords: shareholder protection, capital market regulations, good corporate governance.

\begin{abstract}
Abstrak
Makalah ini membahas reformasi regulasi dalam tata kelola perusahaan Indonesia bersama dengan pasar modal kerangka peraturan yang telah terus-menerus dilakukan dalam menanggapi untuk meningkatkan perlindungan pemegang saham minoritas dan penerapan tata kelola perusahaan di perusahaan publik, terutama dalam melindungi pemegang saham minoritas kanan melalui tiga kasus pendek penelitian. Tiga kasus yang dianalisis dalam makalah ini menunjukkan bahwa penerapan tata kelola perusahaan di perusahaan publik yang terdaftar masih lemah, akibat kurangnya kesadaran tentang bagaimana menerapkan tata kelola perusahaan oleh perusahaan publik yang terdaftar, perilaku oportunistik perusahaan publik yang terdaftar dengan menggunakan celah dalam peraturan untuk kelemahan dalam penegakan hukum pasar modal.
\end{abstract}

Kata Kunci: Perlindungan Pemegang Saham, Peraturan Pasar Modal, Tata Kelola Perusahaan yang Baik

\section{Introduction}

In the era of globalization and high economic competition, strengthening the capital markets might be seen as a key economic project. This is because a well-developed capital market will bring immense advantages to developing the economy of the nation. ${ }^{1}$ For instance, the capital markets provide sources of funding for industries as they expand to take advantage of emerging markets. While a well-developed capital market could bring immense advantages to the country's

${ }^{*}$ Legal Counsel Bureau, Ministry of Finance, Republic of Indonesia. The author can be contacted at aprisaban@gmail.com

1 P A Isenmila and Akinola Adewale, 'The Role of Capital Market in Emerging Company' (2012) 2 (6) International Journal of Business and Social Research 62. See also, The Asian Development Bank, Strengthening Indonesia's Capital Market, Project Data Sheets Updated as of 31 March $2014<\mathrm{http}: / /$ www. adb.org/projects/32507-032/details>. 
economy, the fact shows that the current position of Indonesian stock market, compared to Indonesia's nearest neighbours such as Malaysia and Singapore is considerably small. ${ }^{2}$

There are various reasons why the Indonesia capital market is not able to attract larger numbers of investors. In terms of business legal environment, previous several studies refer to the poor investor protection. ${ }^{3}$ While there have been many improvements on the regulatory framework to protect investors, the lack of implementation of the law is still an obstacle. Apparently, a highly concentrated ownership structure in the Indonesian companies led to the weakness in corporate governance. ${ }^{4}$

In this regard, minority shareholder protection is an important element for investors to make a decision to invest in public listed companies. Considering this background, this paper explores the regulatory reform in Indonesia corporate governance along with capital market regulatory framework which has continuously been conducted in response to enhance minority shareholders' protection and the implementation of corporate governance in public listed companies, particularly in protecting shareholder right through three short cases studies.

Although there have been several studies discussing the weak protection of investors in Indonesia, this paper points out the regulations which cover the protection of investors choosing to invest in public listed companies, and analyzes the current cases that depict the type of shareholders' expropriation. This paper then examines the response of capital market supervisory agency in enforcing those cases. The rationale for examining current cases is to frame an argument that if there has been an improvement on the regulatory framework to protect investors in Indonesian capital market, there should have been less chance for companies to expropriate shareholders' right. ${ }^{5}$

However, the three cases analysed in this paper show that the expropriation of minority shareholders still occurs. The reason for weak shareholders' protection ranges from the lack of awareness of how to implement corporate governance by the public listed companies, to the opportunistic behaviour of public listed companies using loopholes in the regulations and weaknesses in the enforcement of capital markets law.

As it plays a dominant role in the area of regulating the capital markets, the

${ }^{2}$ ADB, Asia Capital Market Monitor, Aug 2011 reported that market capitalization in Indonesia was only about 371,3 US $\$$ billion or $45,1 \%$ of GDP, compared to Malaysia 170,8\% and Singapore 223,4\% of GDP.

${ }^{3}$ See, i.e. The Asian Development Bank, Corporate Governance and Finance in East Asia 2 cited in William E Daniel, 'Corporate Governance in Indonesian Listed Companies - A Problem of Legal Transplant - Special Issue: Comparative Corporate Governance’ (2003) 15 (1) Bond Law Review 5, Rafael la Porta, Florencio Lopes-de-Silanes, Andrei Shleifer, and Robert Vishny, 'Corporate Ownership Around The World' (1999) 54 (2) The Journal of Finance, 769 and the World Bank Report, Press Release-Shareholder Rights, Transparency Key to Capital Market Development, December 12, 2010 <http://www.worldbank.org/en/ news/press-release/2010/12/12/shareholder-rights-transparency-key-capital-market-developmentnew-wb-report>.

4 The Asian Development Bank, Corporate Governance and Finance in East Asia, 2 cited in William E Daniel, 'Corporate Governance in Indonesian Listed Companies - A Problem of Legal Transplant - Special Issue: Comparative Corporate Governance’ (2003) 15 (1) Bond Law Review 5.

5 In firms with concentrated ownership, the conflict of interest between majority or controlling and minority shareholders becomes an important issue that might lead to the expropriation behavior by controlling shareholders, such as through equity tunneling which dilute minority shareholders' shares. 
capital markets supervisory agency has mostly been criticized in responding to expropriation of minority shareholders. Yet, in relation to its role and the power given to the agency by the law, there are tensions between its primary function as a 'gatekeeper' in the securities market, and the extent to which its power reaches out to protect investors. In relation to that, this paper argues that there is an extensive power of the agency to enforce the law, yet that power is not accompanied by an enforcement strategy. As a consequence, there has been unlimited discretion in enforcing the law. Without a clear approach to enforcement, it has a tendency to create an inconsistency in legal enforcement.

This paper's goal in examining the above cases and exploring capital market regulations and its enforcement is to gain an understanding not only of the legal issues and challenges that exist in implementing capital market regulations in the area of investor protection but also to possibly recommend possible ways to improve the law enforcement in order to ensure effective protection of shareholders in the Indonesian capital market.

The remainder of this paper is organized as follows. The next section of this paper provides the legal framework of the Indonesian capital market. Section III explains the role of the supervisory agency in capital markets. Section IV examines current cases which illustrate types of shareholder expropriation and the role of supervisory agency in responding to such cases. The last section of this paper gives recommendations and conclusion.

\section{An Overview of the Indonesian Capital Market, its Law and Derivative Regulations}

\section{A. Indonesian Stock Market to date}

The capital market is one of the key drivers of a nation's economic growth. Currently, there has been 501 Public Listed Companies in Indonesian capital market. The share ownership composition is still dominated by foreign investors at $57.80 \%$, while the major share ownership based on the type of investors is dominated by corporate, followed by financial institution. ${ }^{6}$ Indonesia is ASEAN's largest economy ${ }^{7}$, but the markets remain uncompetitive by ASEAN countries comparison and unrepresentative of the economy as a whole. ${ }^{8}$ Compared to its regional peers, Indonesian capital markets are smaller. Securities and equity markets are relatively underdeveloped and market capitalization of Indonesia's listed companies is lower than that of its regional peers. ${ }^{9}$

${ }^{6}$ Otoritas Jasa Keuangan, Statistik Pasar Modal, 30 September - 4 Oktober 2013 [Financial Services Authority Capital Market Statistic Report, September 30-October 4, 2013] 30-5 <http://www.ojk.go.id/ DocLib/ViewDocumentPDF.aspx?DocumentGuidId=f5fc5215-5be5-4823-80cb-4c7afa72e21c .

7 ASEAN Latin Business Forum 2012-Towards a Sustainable Future, Indonesia <http://www. asean-latin2012.com/indonesia.html>.

${ }^{8}$ Global Business Guide Indonesia, Finance Capital Markets Overview (2012) <http://www.gbgindonesia.com/en/finance/article/2011/capital_markets_overview.php>.

9 Based on the data of the World Bank, Indonesian market capitalization of listed companies in 2012 was US\$396,772,107,424. Compared to Malaysia and Singapore, Indonesian market capitalization was smaller than them. Malaysia was 476,340,035,965 and Singapore was $414,125,808,743$. Indonesia- 
The growth of business groups with political connections has been the main problem of the Indonesian corporate governance, particularly in the era of former president Suharto's new order government, whereby the mix of politics and business led to rampant corruption. ${ }^{10}$ After the fall of the Suharto regime, there are still doubts about the continuity of conflict of interest which occurs when family members and close associates of government officials conduct their business. In relation to the degree of protection of investors' interest, it has been argued that the political power of group affiliates have preferential access to extracting more value from a weak legal enforcement environment. ${ }^{11}$

On the side of domestic investors, there have been several issues which make Indonesians less interested in investing in capital market, such as lack of knowledge about investment in capital market. Meanwhile, this condition has been compounded by the trauma of being cheated by investment brokers. For example, the securities scam involving PT Sarijaya Permana Sekuritas ${ }^{12}$ and PT Antaboga Delta Sekuritas ${ }^{13}$ had severe negative repercussions and caused big financial losses to investors, diminishing the investors' trust on capital market. From the perspective of foreign investors, the Indonesian legal environment, particularly in relation to protection of shareholders ${ }^{14}$, firm-level corporate governance, ${ }^{15}$ become considerable issues in deciding invest in Indonesian capital market.

\section{B. Indonesian Financial Services Authority: Regulating and Supervising the Market}

To help public investors make informed investments decisions and to protect them from harmful and illegal practices, a Capital Market Supervisory Agency is authorized to administer and supervise the capital market. The Capital Market Supervisory Agency has authorities to enforce the Law and ensure the capital market is conducted in an orderly and fair maner. Previously, Indonesian capital markets were supervised by the Capital Markets and Financial Institutions Supervisory Agency (Bapepam-LK). Bapepam-LK's Chair was appointed by the President and was responsible to the Minister of Finance. Before purely conducting its functions as a supervisor, Bapepam ${ }^{16}$ was

\footnotetext{
Investments, Finance <www.indonesia-investments.com/finance/item6 $>$.

${ }^{10}$ Bill Guerin, 'Politics and business mix in Indonesia', Asia Times (online), 22 July 2006 <http:// www.atimes.com/atimes/Southeast_Asia/HG22Ae01.html>.

11 Ibid.

12 Ika Krismantari and Dicky Christanto, 'Sarijaya Named in Securities Scam' The Jakarta Post (on-
} line), 7 January 2009 <http://www.thejakartapost.com/news/2009/01/07/sarijaya-named-securitiesscam.html>.

13 Ramona Sofiannew Dewi, Bonardo Maulana Wahono, Archie Ardian, 'Antaboga Mutual Funds Investigated', VivaNews (online), 3 December 2008 < http://m.news.viva.co.id/news/read/13359-antaboga mutual funds investigated $>$.

14 Akbar Komijani and Habib Soheili Ahmadi,' Analysis of the Role of Protecting Shareholders Rights in Expanding Stock Market in a Selected Developing Countries' (2012) 3 (17) International Journal of Business and Social Science.

15 Chandrasekhar Krisnamurti, Aleksandar Sevic and Zeljo Sevic, 'Legal Environment, Firm-level Corporate Governance and Expropriation of Minority Shareholders in Asia' (2005) 38 Economic Change and Restructuring.

${ }^{16}$ Before Bapepam-LK, the organization which supervised capital market area was Bapepam. This supervisory agency then integrated with financial institutions supervisory agency under the Bapepam-LK. 
also an organizer of the stock exchange. In 1990, these twin tasks were eliminated. Bapepam then focused on its function as a supervisor in capital market. In December 2005 by a merger with the Directorate General of Financial Institutions, it became Bapepam-LK. After the merger, the authority covers the supervision of insurance and pension industries. In supervising capital market industries, Bapepam-LK has authorities to guide capital market industry, including enacts technical regulations, supervises on day to day market activities, investigates the capital market violations, and imposes sanctions.

However, the current organization structure and supervisory approach maintain separate structure for each sectore. For example, the organization structure has separate chief excecutives for capital market, non-bank financial institution, and banking. ${ }^{17}$ With this structure, OJK may face an obstacle to leverage or adopt a fully integrated approach to supervision. Therefore, one of the priority tasks is to enhance cross-sectoral knowledge and fully integrate capital market, non-bank financial institution, and banking supervision under OJK. In other words, OJK must immediately harmonise supervisory approaches across sectors, and develop reporting structures and processes in order to prevent supervisory team in each sector work in sectoral framework. ${ }^{18}$

Report by OJK indentifies that at least 31 conglomerates in the financial services sector which mostly controlled by bank. They also have a limited amount of non-banking financial business. ${ }^{19}$ An integrated approach to supervise financial services is important since the existence of conglomerates in the Indonesia financial services industry might expose risks associated with this type of grouping company, such as concentration of family ownership, pyramiding, and cross shareholding.

\section{The power given by the law}

Because the current Capital Market Law and its implementing regulations are yet to be revised and the cases explained in this article occured before the transition from Bapepam LK to 0JK, further explanations of this article sometimes still refer to the former organization, either Bapepam or Bapepam LK.

Most of the provisions of the Law No 8 of 1995 Concerning Capital Market (the Capital Market Law) give authority to OJK (former Bapepam LK), yet they do not give strict obligations to enforce the law such as in investigating criminal violation in capital market. For instance in Article 5 states:

"In order to carry out the provisions of Articles 3 and 4, BAPEPAM shall have authority to:

a. Inspect and investigate any Person with respect to suspected violations of this Law or its implementing regulations; ..."

Similarly, Article 100 states:

\footnotetext{
${ }^{17}$ Otoritas Jasa Keuangan, 'Struktur Organisasi OJK' < http://www.ojk.go.id/struktur-organisasi >.

${ }_{18}$ Financial Stability Board (2014) 'Peer Review of Indonesia-Review Report', FSB Report.

19 Fathan Qorib, Andin Aditya Rahman (2014) 'Facing AEC, OJK Prepares Banking Sector's Resilience Policy', hukumonline, 27 June < http://en.hukumonline.com/pages/lt5379bf7ed8ff2/facing-aec-ojkprepares-banking-sector-s-resilience-policy>.
} 
(1) "Bapepam may initiate a formal investigation of any person suspected of violating or being involved in a violation of this Law and/or its implementing regulations."

The above provisions imply that 0JK has discretionary powers to supervise the markets. Consequently, major regulatory activities taken by OJK are based on discretion. This includes the enforcement of measures which involve allegations for criminal conduct. The case of Bank Pikko is one of examples in which OJK used their discretionary power to discontinue criminal investigation. ${ }^{20}$ If OJK decides not to proceed with an investigation, a common measure taken by Bapepam is to impose administrative sanctions. ${ }^{21}$ This would be based on Article 102 which provides for the imposition of administrative sanctions for violations of the Capital Market Law and its implementing regulations. This provision makes the imposition of administrative sanctions to even criminal violations as long as this violation is governed by the Capital Market Law. Generally, OJK might use this provision on criminal violation in capital markets where Bapepam considers not preceding with a criminal investigation.

The approach of regulatory enforcement taken by OJK is similar to that of ASIC (the Australian Securities and Investments Commission). The conceptual regulatory organization framework taken by ASIC tends to be transactionfocused. For instance, it draws up notices to seek information in response to a complaint about misconduct or commence a formal investigation into suspected misconduct with a view to bringing administrative, civil or criminal action against violations if the evidence supports it. ${ }^{22}$

However, one should note that the conceptual regulatory framework that created the ASIC authority supplied that policy. ${ }^{23}$ Although, the typical authority provisions which empower Bapepam to conduct its supervision tend to be exercised by discretion, a clear policy direction should lead OJK in exercising its discretion. In the Capital Market Law there are no precise requirements concerning enforcement. The only clear conceptual underpinning what drives Indonesian capital market policy implementation is to ensure the investors protection. In regards to this objective, an approach of enforcement in capital market should proportionally

${ }^{20}$ Elucidation of art 101 Law No 8 of 1995 Concerning Capital Market states that:

'Capital Market misbehaviour varies in type, modus operandi, and potential for loss. For this reason, BAPEPAM is authorized to consider the consequences of a violation and has discretion to proceed with an investigation, based on its judgment. BAPEPAM is not required to initiate a criminal investigation for every violation of this Law and its implementing regulations, since such a course of action might inhibit general business in the Securities market. When the harm inflicted endangers the Capital Market system, the interests of investors or the public, or when a settlement is not reached with respect to losses, BAPEPAM may initiate a criminal investigation. The Chairman of BAPEPAM orders the initiation of investigations by Criminal Investigators on BAPEPAM staff.'

${ }^{21}$ Article 102 the Law No 8 of 1995 Concerning Capital Market states that 'Bapepam may impose administrative sanctions for violations of this Law and/or its implementing regulations against every Person that is licensed, approved or registered with Bapepam'.

${ }^{22}$ Justin O’Brien, Private Equity, Corporate Governance and the Dinamics of Capital Market Regulation (Imperal College, Press 2007) 9.

${ }^{23}$ The provision which given ASIC authority is stipulated in s 1 of the Australian Securities and Investments Commission Act 2001 (cth). Malcolm Rodgers, former Executive Director, Regulation at the ASIC stated that 'the Act and other legislation we administer create obligations for us and give us extensive and sometimes intrusive powers to go about our job.... Some parts of it hang together and look like the product of a single mind; others are a patchwork of history, politics, and sometimes dubious drafting.' 
employ an accommodative and a sanctioning approach to compliance.

A common policy of enforcement in the capital market is to enforce administrative sanctions rather than criminal sanctions. The enforcement of the Financial Services Authority (FSA), the UK capital market supervisory agency can be given as an example. In UK, the enforcement approach of FSA is in favour to the administrative nature of the disciplinary process because of flexibility and the less costly formal court procedures. The FSA also learn from the failure to bring deterrence from the criminal sanctions to market abuse contraventions. The approach of FSA also derives from the proposition that:

[A]dministrative sanctions would provide much greater flexibility to bring to book individuals and organizations who had escaped the regulatory net as a result of the evidential and procedural safeguards of the criminal law. ${ }^{24}$

Even though nowadays Indonesia has moved to the integrated approach similar to the UK's financial supervisory institution, a further research need to be taken to assess as to whether a similar approach of enforcement can be adopted in the case of Indonesian capital market.

\section{Law and Regulations in relation to Shareholders Rights}

Before exploring shareholders' experiences in pursuing their rights in Indonesian capital market and consider how to improve protection of investors in the Indonesian capital market, particularly in relation to minority shareholders protection in Indonesian Public Listed Companies, it is important to understand legal framework which covers the protection of minority shareholders. Besides disclosure regulations, the protection of investors in Indonesian capital market is stipulated through regulations which define the mechanism of the change of control transactions, particularly through the imposition of mandatory bid and disclosure requirements in the takeovers laws.

\section{General Legal Framework}

How the rights of shareholders are protected in a company has a correlation with how a company is governed. Having said that, the discussion on the protection of shareholders cannot be separated from the corporate governance principles which are implied in Indonesian Law. As soft law, the Indonesian Code of Good Corporate Governance sets out principles of good corporate governance which cover the protection component of shareholders rights. According to the Indonesian Code of Good Corporate Governance, the rights of shareholders that need to be protected as follows: ${ }^{25}$

a. the right to attend, express an opinion, and vote in the General Meeting of Shareholders based on the provision that one share entitles the right of the holder to issue one vote;

${ }^{24}$ An Article by Iain MacNeil, 'Enforcement of Capital Markets Regulation: The United Kingdom and Its International Markets' compiled in Justin O'Brien, Private Equity, Corporate Governance and the Dinamics of Capital Market Regulation (Imperal College, Press 2007) 175.

${ }^{25}$ The Indonesian Code of Good Corporate Governance cited in William E Daniel, above n 4, 16. 
b. the right to obtain information regarding the company on a timely, proper and regular basis, except with respect to confidential matters, so that the shareholders can make a decision in relation to their investment in the company based on accurate information;

c. the right to receive shares of profit appropriated for shareholders in the form of dividends and other profit sharing, in proportion to the shares owned;

d. the right to obtain full explanation and accurate information with regard to the procedures to be met in relation to the convening of the General Meeting of Shareholders in order for the shareholders to participate in decisions, including those affecting the existence of the company and the rights of the shareholders;

e. in the event that there is more than one type and classification of shares in the company, then: (i) each shareholder is entitled to cast a vote in accordance with the type, classification and number of shares owned; and (ii) each shareholder is entitled to obtain a fair treatment based on the type and classification of the share owned.

The implementation of those codes is stipulated in the Indonesian Company Law, Capital Market Law and its implementing regulations. Generally, the law concerning general limited company is governed by Indonesian Company Law. However, once the market participants engage in Indonesian capital market activities, such as as issuers, they should also pay attention to the law that governs the capital market and its derivative regulations. However, the law that governs public listed company refers to Company Law if there is no specific matter governed by Capital Market law. Thus, Company Law serves as the "lex generalis" for Capital Market Law.

A key feature of Company law is to reduce the opportunistic behaviours among stakeholders. Therefore, compared to the capital market law, the company law is more elaborate in regulating and reducing the conflict between managers and shareholders, among shareholders themselves, and between shareholders and the related stakeholders of the company. ${ }^{26}$ On the other hand, as it has been standardized by International Financial Organizations, ${ }^{27}$ the Indonesian Capital Market Law and its implementing regulations is more focus on ensuring market conduct through disclosure. The objective of the Indonesian Capital Market Law can be seen from its provision that in order to develop capital market, 'its activity must be supervised to ensure that the capital market is orderly, fair, and efficient' ${ }^{28}$ Furthermore, the Law has mandated that the supervision of

${ }^{26}$ Konrad Zweigert and hein Kotz, An Introduction to Comparative Law, (Oxford University Press, 1998) 4 cited in Yozua Makes, 'Challenges and Opportunities for the Indonesian Securities Takeover Regulations: General Framework and Analysis from Dutch Law and Theoretical Perspectives' (2012) Makes International Law Journal 79.

27 Most of the Securities Regulations in many jurisdictions have been standardized according to the International Organization of Securities Commissions (IOSCO). 'IOSCO is a multilateral forum for standard-setting and co-operation between national securities regulators'. IOSCO has 'triple goals of investor protection, market efficiency and systemic stability. This information is extracted from: Robert Baxt, Ashley Black, and Pamela Hanrahan, Securities and Financial Services Law (Lexis Nexis Butterrworths, 8th ed, 2012) 10.

${ }^{28}$ Undang-Undang Republik Indonesia Nomor 8 Tahun 1995 Tentang Pasar Modal [Law of the Republic of Indonesia Number 8 Year 1995 Concerning Capital Market] elucidation of art 3 [unofficial English 
capital market must ensure the protection of investors and public' interest. ${ }^{29}$

In relation to shareholder protection, the basic protection has been regulated by the Company Law, for instance, a right to equal treatment in which the law stipulates that the shares of the same class confer to their holders the same rights. ${ }^{30}$ Another basic right is the shareholders' right to attend and vote in general shareholders meeting. In addition, 'each share shall have one right to vote, unless the article of Association provides otherwise'. ${ }^{31}$

Shareholders also have a right to obtain corporate information in a timely and on regular manner. The Company Law provides the basic right to obtain information stipulating that 'within six months after the close of the company accounting year, the directors shall compile an annual report to the general shareholders meeting after being examined by board of commissioners. ${ }^{32}$

For Public Listed Companies, the Capital Market Supervisory Agency ${ }^{33}$ sets another obligation to report material transactions to Financial Services Authority and the Indonesian Stock Exchange within two days after the date of transaction. ${ }^{34}$ Further detailed obligations to disclose corporate information are regulated in Capital Market law and its regulations will be discussed below.

\section{Transparency through Disclosure Requirements}

Generally, in the capital market, the regulations on publicly listed companies are mostly related to disclosure and transparency principles. A strong disclosure regime in financial markets is very important because it has an impact on confidence of the investors. Under disclosure requirements, public listed companies are expected to provide transparency regarding the firm's performance and governance to investors. As a common measure in regulating the market, disclosure requirements provide reliable and timely information to investors. Thus, it enables investors to make investment decisions based on material information that they need. ${ }^{35}$

Generally, this type of regulation is similar among jurisdictions due to the

trans].

29 Undang-Undang Republik Indonesia Nomor 8 Tahun 1995 Tentang Pasar Modal [Law of the Republic of Indonesia Number 8 Year 1995 Concerning Capital Market] art 3 [unofficial English trans].

${ }^{30}$ Undang-Undang Republik Indonesia Nomor 40 Tahun 2007 Tentang Perseroan Terbatas [Law of the Republic of Indonesia Number 40 of 2007 Concerning Limited Liability Company] art 53(2) [unofficial English trans].

${ }^{31}$ Undang-Undang Republik Indonesia Nomor 40 Tahun 2007 Tentang Perseroan Terbatas [Law of the Republic of Indonesia Number 40 of 2007 Concerning Limited Liability Company] art 72(1) [unofficial English trans].

${ }^{32}$ Undang-Undang Republik Indonesia Nomor 40 Tahun 2007 Tentang Perseroan Terbatas [Law of the Republic of Indonesia Number 40 of 2007 Concerning Limited Liability Company] art 66(1) [unofficial English trans].

33 Previously, Indonesian capital market is supervised by Capital Market and Financial Institution Supervisory Agency (Bapepam-LK). Recently, in 2013, the new integrated agency which supervises all financial services institutions, including banking is established, namely Financial Services Authority. A further discussion is explained in the next chapter.

${ }^{34}$ Badan Pengawas Pasar Modal dan Lembaga Keuangan (hereinafter referred to as Bapepam-LK) Rule Number IX.E.2 Concerning Material Transaction and Changing in Core Business.

${ }^{35}$ Technical Committee of the International Organization of Securities Commission, Principles for Periodic Disclosure by Listed Entities, Final Report (February 2010) 3. 
standardization by the International Organization of Securities Commissions (IOSCO). ${ }^{36}$ In the Indonesian capital market, the disclosure requirements for public listed company fall within two categories. Firstly, a primary market disclosure requires a company to comply with disclosure requirements when a company issues securities for the first time. ${ }^{37}$ Further requirements should be fulfilled by a company through continuous disclosure such as annual report, ${ }^{38}$ financial report ${ }^{39}$ and the obligation to disclose material transactions, ${ }^{40}$ affiliated party transactions and conflicts of interest in certain transactions. ${ }^{41}$

\section{The Need for Disclosure of Beneficial Ownership and Control}

To avoid conflict of interest, the Financial Services Agency also regulates disclosure for shareholders who own $5 \%$ or more of shares. ${ }^{42}$ However, this rule only stipulates the obligation to inform the direct owners of shares. In order to improve capital market transparency and to meet the International minimum standard of corporate governance, the Organization for Economic Cooperation and Development (OECD) recommends that the Indonesian capital market supervisory agency ${ }^{43}$ should 'extend its disclosure requirement to include beneficial ownership.' ${ }^{44}$

${ }^{36}$ One of the main principles for issuers set by IOSCO is: 'there should be full, accurate and timely disclosure of financial result, risk and other information which is materials to investors' decisions'. International Organization of Securities Commission, 'Objective and Principles of Securities Regulation' (June 2010) 8. IOSCO has many members such as Australia, US, and Canada. Although the IOSCO recommendations can be considerate as soft law to ensure its implementation, IOSCO sets individual settlement systems. Australia is one of the members of IOSCO. In Australia, regulations to protect minority shareholders are also imposed by disclosure requirements. Robert Baxt, Ashley Black, and Pamela Hanrahan, above $n$ 22,5 .

37 There are many rules which regulate the mechanism of disclosure in initial public offering, such as procedures to issuing prospectus in Bapepam-LK Rule Number IX.A.1 Concerning General Requirements Regarding Submission of a registration Statement, Bapepam-LK Rule Number IX.A.8 Concerning Preliminary Prospectus and Information Memorandum, Bapepam-LK Rule Number IX.C.1 Concerning Form and Content of a Registration Statement for a Public Offering, Bapepam-LK Rule Number IX.C.2 Concerning Guidelines Concerning the Form and Content of a Sumary Prospectus for a Public Offering, Bapepam-LK Rule Number IX.C.3 Concerning Guidelines Concerning the Form and Content of a Summary Prospectus for a Public Offering.

${ }^{38}$ Bapepam-LK Rule Number X.K.6 Concerning Obligation to submit annual report for Issuers or Public Companies.

${ }^{39}$ Bapepam-LK Rule Number X.K.2 Concerning Obligation to Submit Periodic Financial Statements.

${ }^{40}$ Bapepam-LK Rule Number IX.E.2 Concerning Material Transaction and Changing in Core Business.

${ }^{41}$ Bapepam-LK Rule Number IX.E.1 Concerning Conflicts of Interest on Certain Transactions.

42 Undang-Undang Republik Indonesia Nomor 8 Tahun 1995 Tentang Pasar Modal [Law of the Republic of Indonesia Number 8 Year 1995 Concerning Capital Market] art 87(2) and Bapepam-LK Rule Number X.M.1 Concerning Disclosure Requirements for Certain Shareholders.

43 In 2012, Indonesia has a new and independent capital market supervisory agency which integrated with banks and other financial institutions under Financial Services Authority or Otoritas Jasa Keuangan (OJK). Previously, the supervisory agency was a part of Ministry of Finance, namely Badan Pengawas Pasar Modal dan Lembaga Keuangan (Bapepam-LK). Meanwhile the supervision of bank was under Bank Indonesia.

${ }^{44}$ Fianna Jurdant, 'Disclosure of Beneficial Ownership and Control in Indonesia: Legislative and Regulatory Policy Option for Sustainable Capital Markets' (OECD Corporate Governance Working Papers No 9, OECD, 2013) 8. 
However, Bapepam Rule ${ }^{45}$ Number X.M.1 Concerning Disclosure Requirements for Certain Shareholders does not cover the obligation to inform the indirect owners. This rule does not extend a requirement for persons who are able to acquire such owner's own initiative and who have the power to vote or to direct the voting or to dispose or to direct the disposition of one or more outstanding shares of a company to disclose their indirect owners. ${ }^{46}$ Thus, it is argued that investors still find a difficulty in identifying the ultimate beneficial owner.

Furthermore, it has been argued that with the current minimum requirement to provide disclosure of direct equity ownership, this regulation might not be effective because of the practice of omnibus account maintained by a custodian or sub-custodian. Commonly, the account opened by market players in Indonesian Central Securities Depository (Kustodian Sentral Efek Indonesia/ KSEI) by the rule is undertaken through Securities Company and Custodian Bank. ${ }^{47}$

While Indonesian corporate governance system is characterized by concentrated ownership, the existence of a disclosure framework that provides information in the beneficial ownership and control structures of public listed company is necessary. In the absent of ultimate ownership and control reporting mechanism, the expropriation of minority shareholders potentially might not be detected. For instance, a controlling shareholder might force management to enter related party transaction or employ a strategy to extract resources and assets from the company that he controls. It then possibly leads to insider trading or dilutive share issues. ${ }^{48}$

\section{Misleading Information}

In the financial market, there are various types of defective disclosures in connection with securities and other financial products. ${ }^{49}$ For instance, breach of disclosure of bidder's statement or a takeover offer document and disclosure of a prospectus of offer information statement. Another breach of disclosure is a misleading or deceptive conduct in relation to financial product, such as securities. ${ }^{50}$

Principally, a breach of those disclosure regimes may make persons liable to investors for defective disclosure. Furthermore, as this might result in loss to the investors, there is usually a mechanism for 'a person who owns or acquires a security in the primary or secondary market to claim for damages or other remedies arising out of that defective disclosure.' ${ }^{51}$

In Indonesia, the disclosure regime for public listed companies, Indonesian

45 This regulation was enacted when the capital market supervisory agency (Bapepam) was still separated from financial institutions supervision under the Directorate General of Financial Institutions. Both institutions were under Ministry of Finance. When both Bapepam and Directorate General of Financial Institutions were merged, the institution was called Bapepam-LK.

${ }^{46}$ Fianna Jurdant, above n 39, 9.

47 Bapepam-LK Rule Number III.C.7 Concerning Securities Sub Account With Central Securities Depository, point $1 \mathrm{c}$.

${ }^{48}$ Fianna Jurdant, above $\mathrm{n} 39,13$.

49 Robert Baxt, Ashley Black, and Pamela Hanrahan, above n 39, 311.

50 These types of defective disclosure are taken in the regime of investor protection provisions in Australia Securities and Financial Services Regulations. Robert Baxt, Ashley Black, and Pamela Hanrahan, above $\mathrm{n} 39,312$.

51 Ibid. 
capital market law governs the claim for misleading information on the Registration Statement of a Public Offering or misleading statement because of the omission to provide material information required by the Capital Market Law and its regulations. ${ }^{52}$ Likewise, for takeover, there is an obligation for the new owner 'to provide to the public information concerning the takeover no later than 2 working days after the takeover'. ${ }^{53}$

The difference between the above two claims (misleading information in registration statement and takeover announcement) is that for the first claim; the statutory claim for loss or damage could refer to article 80(4) Capital Market Law which provides specific recognition for the breach of misleading information in a prospectus of offer information statement. Meanwhile for the misleading information in takeover statement, the more general provision in article 111 Capital Market Law provides the claim for losses arising from violation of this Law and implementing regulations, including the regulation related to open company takeover. ${ }^{54}$ For the implementation of corporate governance, Indonesian Capital Market Law also specifies persons liable for defective disclosure, particularly for misleading information in registration of initial public offering. ${ }^{55}$

While the law provides the mechanism to claim for investors' loss due to misleading information, the evidence of loss is an essential part for a plaintiff to bring the case under the allegation of breach of misleading information. The plaintiff must prove that he/she has suffered loss by conduct of a person or persons in contravention of those sections. In terms of loss, the plaintiff must prove that the loss that he/she suffered is caused by the conduct of that person; for example that one was misled in the purchase of securities and consequently suffered loss. Importantly, the plaintiff must prove that the loss did not derive from his/her fault of calculation in investment decision. ${ }^{56}$

\section{Market Conduct in relation to Takeover}

The law governing takeovers is an essential matter for the development of capital markets. If the process of takeover is conducted with proper corporate governance, it can facilitate efficient exchange of shares in the capital market with fair protection for all stakeholders. ${ }^{57}$ The law in relation to takeovers differs from one to another and might depend on the market and corporate structure. As in Indonesia, the corporate structure is mainly concentrated in family group ownership. This shapes the takeover mechanism which might differ from the market in which the dispersed ownership is dominated. As ownership is concentrated, it is important to protecting the interests of minority shareholders from the tendency of expropriation by the controlling shareholders. On the other

52 Undang-Undang Nomor 8 Tahun 1995 Tentang Pasar Modal [The Law Number 8 Year 1995 Concerning Capital Market] art 80 (4) [unofficial English trans].

${ }_{53}$ Bapepam-LK Rule Number IX.H.1 Concerning Open Company Takeover point 2(a).

54 Undang-Undang Republik Indonesia Nomor 8 Tahun 1995 Tentang Pasar Modal [Law of the Republic of Indoensia Number 8 Year 1995 Concerning Capital Market] art 111 [unofficial English trans].

55 Undang-Undang Republik Indonesia Nomor 8 Tahun 1995 Tentang Pasar Modal [Law of the Republic of Indoensia Number 8 Year 1995 Concerning Capital Market] art 80 [unofficial English trans].

${ }_{56}$ Robert Baxt, Ashley Black, and Pamela Hanrahan, above n 39, 339.

57 Yozua Makes, 'Challenges and Opportunities for the Indonesian Securities Takeover Regulations: General Framework and Analysis from Dutch Law and Theoretical Perspectives' (2012) Makes International Law Journal 4. 
hand, as the conflicting interests between shareholders and the management are not an issue in corporate structure in the Indonesian market, friendly takeovers are more common than hostile takeover. ${ }^{58}$

Takeover is one corporate action which might support an increase of investment. Generally, takeover of a public company can be done by acquisition of shares in the company. Under the Indonesian Company Law, acquisition is defined as 'a legal act performed by a legal entity or individual personal to acquire shares in a company resulting in the change of control of the company'. ${ }^{59}$

The general rule of acquisition which is provided by the Indonesian company Law requires a minimum quorum in the General Meeting of Shareholders where 'at least three quarters of the total number of shares with voting rights is present or represented in the GMS. ${ }^{60}$ Furthermore, 'the resolution is lawful if approved by at least three quarters of the number of votes cast. ${ }^{61}$

Meanwhile, for the takeover mechanism specified for a public company, the capital market law as the lex specialis of the Company Law differs in the procedures. ${ }^{62}$ The mechanism for the transfers of rights over shares traded on capital markets is stipulated in Bapepam-LK Rule No. IX.H.1. 2011. Under this specific regulation, the requirement to obtain approval from the GMS is excluded. However, the approval might be obtained if it is required by other specific laws or and regulations which govern the company's line of business. ${ }^{63}$

Special attention should be given to Rule Number IX.H.1 Concerning Open Company Takeover. This regulation requires disclosure, fairness and reporting for open company takeover. There have been several updated versions until the last regulation enacted in 2011 in order to response the aspiration of investors and legal advisors. The first version was enacted in 2000, then amended and replaced in 2002. A further enactment was in 2008 which significantly changed the mandatory selling requirement. As the takeover regulation has a correlation with the tender offer regulation, ${ }^{64}$ this regulation was also being amended to adjust to the takeover regulation.

\section{In 2011, Bapepam-LK amended the regulation of tender offer which differs}

${ }^{58}$ Ibid 73-5. In a type of company's structure which is characterized by the disperse ownership structure, the common practice of takeover of public listed company is conducted by a hostile takeover, i.e. public offer, it then leads to the acquisition. A public offer in the event of hostile takeover has a purpose to balance the power between shareholders and management in relation to the takeover bid action. In a public offer process for example, a hostile offer or should consult with the target company for a certain period and inform the bid price.

${ }^{59}$ Undang-Undang Republik Indonesia Nomor 40 Tahun 2007 Tentang Perseroan Terbatas [Law of the Republic of Indonesia Number 40 of 2007 Concerning Limited Liability Company] art 1(11) [unofficial English trans].

${ }^{60}$ Undang-Undang Republik Indonesia Nomor 40 Tahun 2007 Tentang Perseroan Terbatas [Law of the Republic of Indonesia Number 40 of 2007 Concerning Limited Liability Company] art 89(1) [unofficial English trans].

${ }^{61}$ Undang-Undang Republik Indonesia Nomor 40 Tahun 2007 Tentang Perseroan Terbatas [Law of the Republic of Indonesia Number 40 of 2007 Concerning Limited Liability Company] art 89(1) [unofficial English trans].

${ }^{62}$ Undang-Undang Republik Indonesia Nomor 40 Tahun 2007 Tentang Perseroan Terbatas [Law of the Republic of Indonesia Number 40 of 2007 Concerning Limited Liability Company] art 56(5) [unofficial English trans].

${ }^{63}$ Bapepam-LK Rule Number IX.H.1 2011 Concerning Open Company Takeover point 3b.

64 Bapepam-LK Rule Number IX.F.1 Concerning Tender Offers. 
from the requirements and procedures for a mandatory tender offer and for a voluntary tender offer. Thus, today, Bapepam-LK Rule Number IX.H.1 regulates the conduct of a mandatory tender offer and Bapepam-LK Rule Number IX.F.1 regulates the voluntary tender offer procedure.

The intention of Bapepam-LK to revise the law concerning Open Company Takeover in Regulation Number IX.H.1 in 2011 was to 'increase an open company's shares liquidity and in order to provide more opportunity for investors to access and or own open company' shares. ${ }^{65}$ Meanwhile the revision of BapepamLK Rule Number IX.F.1 was in order to amend the law of voluntary tender offer with the new mandatory tender offer procedures. The amendment is needed due to the drastic revision of Bapepam-LK Rule Number IX.H.1 in 2008.

The new regulation of takeover in open company changes the policy of Mergers and Acquisitions in the country. The Capital Market Supervisory Agency regulates the requirement for "mandatory offer" which occurs if a takeover changes in a company's control. Previously, the definition of company controller which falls within the obligation of mandatory offer is for a share ownership threshold of $25 \%$ or more. Under the new regulations, it increases to more than $50 \%$. The purpose of introducing the new rule is to increase liquidity by requiring a share ownership threshold of more than $50 \%$ in order to trigger a mandatory tender offer.

Unlike the old regulation which used "highest price" to calculate share purchase price, the new regulations have a new method for calculating share purchase price, namely "average highest price". This new method minimizes the possibility of price manipulation. For instance, due to leaked information, the artificial price is created by inflating the market price.

\section{Material Transaction}

The Material Transaction rules are stipulated in Bapepam-LK Rule Number IX.E.2 2011. Previous rules were published in 2009. In these new rules, there are several improvements ${ }^{66}$ as follows. First, the definition of material transaction is simplified. Material transactions that need to be disclosed have a value of $20 \%$ to $50 \%$ of the public company's equity. It must be disclosed within two business days after the transaction which is counted after the signing of the transaction documents. ${ }^{67}$ This revised provision clarifies the time to announce information on a Material Transaction.

Secondly, the exemptions for material transaction are expanded. For instance, if a company or its subsidiary companies receives loans, there is an exemption for the grant of securities by a listed company to financial institutions, such as banks,

${ }^{65}$ Consideration point a of the Decision of Chairman of Capital Market and Financial Institutions Supervisory Agency Number: KEP-259/BL/2008 Concerning Open Company Takeover (Bapepam-LK Rule Number IX.H.1 2008).

${ }^{66}$ Herbert Smith, 'Indonesia-changes to Bapepam-LK material transaction rule (Part 2) and clarification on currency law requirement to use Rupiah for payments', e-bulletin, 20 December $2011<$ http:// www.hbtlaw.com/uploads/File/publications/20111220\%20\%20\%20Indonesia $\% 20 \% 20$ changes $\% 20$ to\%20BapepamLK\%20materialtransaction\%20rule.htm>.

67 Bapepam-LK Rule Number IX.E.2 Concerning Material Transactions and Change of Main Business Activities, point 1 and point 2. 
venture capital companies, or infrastructure finance companies either onshore or offshore ${ }^{68}$ This provision clarifies the previous rule which did not explain the scope of loans.

There also have been changes in relation to the business activities rules. If a public listed company wants to change main business activity from its subsidiary company, the prior approval from the public listed company's shareholders is only required if the contribution of the revenue of its subsidiary company is $20 \%$ or more. ${ }^{69}$ Previously, the prior approval was required in all circumstances. ${ }^{70}$

\section{Shareholder Litigation}

One of the important methods and perhaps a pragmatic solution for corporate governance is litigation as a derivative action protecting the rights of shareholders. To protect the rights of minority shareholders, the Company Law provides safeguards share holders on behalf of the company can take an action against a member of the board of directors who due to his mistake or negligence has caused the company to suffer a loss'. ${ }^{71}$ However, the right to represent the company can only be exercised if a shareholder has at least $10 \%$ of the issued shares with valid voting rights. ${ }^{72}$ This requirement can create barriers for shareholders who only own small portions of shares and where there is apparent dispersion of share ownership. Unfortunately, this provision does not open the possibility for a minority shareholder who has shares less than $10 \%$ to collect the voting rights from other shareholders in order to reach threshold.

To cope with the obstacle in the Company Law which limits the threshold requirement, the Capital Market Law facilitates shareholders who suffer losses to sue for compensation either jointly or severally with others with similar claim. ${ }^{73}$ Thus, there is no limitation or threshold for shareholders to sue against a member of board who responsible for the company's loss. This applies specifically to shareholders in Public Listed Companies.

Basically, the Capital Market Law does not specifically facilitate shareholders in relation to their rights in a Public Listed Company. The provision of Article 111 provides as follows:

Any Person who suffers losses arising from violations of this Law or its implementing regulations can sue for compensation, either jointly or severally with other Persons with similar claims, against the Person or

\footnotetext{
${ }^{68}$ Bapepam-LK Rule Number IX.E.2 Concerning Material Transactions and Change of Main Business Activities, point 3.

${ }^{69}$ Bapepam-LK Rule Number IX.E.2 Concerning Material Transactions and Change of Main Business Activities, point 4.

${ }^{70}$ Herbert Smith, above n 61.

${ }^{71}$ Undang-Undang Republik Indonesia Nomor 40 Tahun 2007 Tentang Perseroan Terbatas [Law of the Republic of Indonesia Number 40 of 2007 Concerning Limited Liability Company] art 97(6) [unofficial English trans].

72 Undang-Undang Republik Indonesia Nomor 40 Tahun 2007 Tentang Perseroan Terbatas [Law of the Republic of Indonesia Number 40 of 2007 Concerning Limited Liability Company] art 97(6) [unofficial English trans]. See also the discussion in Benny S Tabalujan, Indonesian Company Law A Translation and Commentary, (Singapore: Sweet \& Maxwell Asia, 1997) 193.

73 Undang-Undang Republik Indonesia Nomor 8 Tahun 1995 Tentang Pasar Modal [Law of the Republic of Indonesia Number 8 Year 1995 Concerning Capital Market] art 111 [unofficial English trans].
} 
Persons responsible for such violations.

Based on the above wording, this provision broadly applies to 'any person, a company, a partnership, an association or any organized group, either when he/she acts as a plaintiff or defendant.' ${ }^{74}$ Another broad concept of derivative litigation in Capital Market Law on this provision also points out that there should be violations of Capital Market Law and or its implementing regulations and the losses deriving from its violation need to be proven before the action brought to a court against a violator.

In practice, it is unclear as to whether the violation must first be proved by the authorities, OJK or it can be proved through a court together with the claim for compensation. In one case, the court interpret Bapepam LK (now OJK) as an extrajudicial organization and based on its function, any breach of capital market law must be prove first by the Authority before any claim for compensation due to the violation in capital market law and its implementing regulations. ${ }^{75}$ The court refers to the Article 5 of the Capital Law that stipulates the organisation has the authority 'to inspect and investigate any Person with respect to suspected violations of this Law or its implementing regulations' ${ }^{76}$ If this decision is being followed by other next cases, there will be long process for investors to pursue compensation due to violation in capital market law and its implementing regulations. On the other hand, if Article 111 of the Capital Market Law is defined in a broad interpretation, Indonesian court can also exercise violation in capital market law in order to decide the award of compensation.

\section{III.The Implementation of Shareholder's Protection in Indonesian Listed Companies}

According to the last IOSCO Report, 'the initial and ongoing disclosure regimes, minority shareholders protection in Indonesia are in place and being enhanced'. ${ }^{77}$ As the success of law reform not only focuses on legal structures and substantive law, but also on the implementation, below I discuss how the law is implemented through the current cases. A study on the implementation on Corporate Governance in Indonesia, June 1999 conducted by Bapepam concluded that the Indonesian regulatory framework has covered almost all the principles of corporate governance in the OECD. However, the challenge of implementation remains as the cases below show.

\section{A. PT Bumi Resources Tbk case}

The potential expropriation of minority shareholders occurred when the company, PT Bumi Resources Tbk (Bumi Resources) conducted a takeover

${ }^{74}$ The definition of Person in art 1(23) of Law of the Republic of Indonesia Number 8 Year 1995 Concerning Capital Market applies to a natural person, a company, a partnership, an association or any organized group.

${ }^{75}$ Abdul Malik Jan v PT Media Nusantara Citra Tbk, dkk, Decision of the District Court of Central Jakarta No 29/PDT.G/2011/PN.JKT.PST (21 June 2011).

${ }^{76}$ Article 5 Law No 8 of 1995 Concerning Capital Market.

77 Financial Sector Assessment Program, 'Indonesia: Implementation of the IOSCO Objectives and Principles of Securities Regulation' (IMF Country Report No 12/189, IMF, July 2012) 8. 
transaction. Under the control of Bakrie business group, PT Bumi Resources has its main business in gas and mining. ${ }^{78}$ The Bakrie family is a prominent business family in Indonesia involved in various and important Indonesian economic sectors, including oil and gas, palm oil, property, mining, telecommunications and finance. ${ }^{79}$ The founder of this family business is Abdurizal Bakrie, a politician. ${ }^{80}$ Due to his position, many critics point out a possible conflict of interest between his business group and the family's political connections. ${ }^{81}$ The issue of conflict of interest between Bakrie's strong position in Indonesian politics and his business have been discussed and criticized, particularly in a recent corporate action taken by PT Bumi Resources Tbk. ${ }^{82}$

It has been alleged that the acquisition of three coal companies by PT Bumi Resources Tbk breached the capital market regulations. Nevertheless, the Bapepam LK had not yet enforced this case. Following this, there has been debate and difference in interpreting the law between the regulator and regulated entity in this case, particularly Bapepam Rule No. IX.E.2 2001.

In this case, the capital market supervisory agency has been criticized for its perceived failure to properly enforce the law' ${ }^{83}$ In order to gain understanding in what is the core of the problematic acquisition by Bumi Resources, the interconnection between what is written in the regulations and its implementation are discussed below, along with this the debatable interpretation and how the authority responded.

Was there any material transaction on the acquisition by PT Bumi Resources Tbk?

While the supervising board, Bapepam LK indicated that the acquisition was a material transaction and changed the main business activity, PT Bumi Resources Tbk insisted that the acquisition was not a material transaction because the corporate actions cannot be interpreted as one action.

Through its subsidiary company, PT Bumi Resources Investment (whose shares are controlled by Bumi Resources) took over the three

78 Bumi Resources was established in 1973 and became Public in 1990 under the name of PT Bumi Modern Tbk in which its shares were listed in Jakarta Stock Exchange and Surabaya Stock Exchange. Previously, the majority shares of Bumi Resources held by PT Asuransi Jiwa Bersama Bumiputera 1912 as a controlled shareholder, but in 1997 the shares were sold by PT Asuransi Jiwa Bersama Bumiputera 1912 to PT Bakrie Capital Indonesia. From that takeover, the portion of shares held by PT Bakrie Capital Indonesia was $58.51 \%$. Since the takeover, the main business was changed from hotel and tourism to oil, gas and mining. In 2000, PT Bumi Modern Tbk changed its name to PT Bumi Resources Tbk.

${ }^{79}$ The Economist (2010) 'Face Value: Indonesia's Teflon tycoon, Aburizal Bakrie has survived controversy in business and politics', 14t Jan <http://www.economist.com/node/15278524>.

${ }^{80}$ Abdurizal Bakrie is the Chairman of the Golkar Party and a candidate for Indonesia's 2014 Presidential elections. Previously, in 2004 to 2005 he served as Coordinating Minister for People's Welfare and then in 2004 to 2005 he was Coordinating Minister for the Economy. Although, Abdurizal Bakrie lost his position as Minister, he is still managing the reins of Golkar.

${ }^{81}$ Guerin, Bill (2006) 'Politics and business mix in Indonesia', Asia Times, 22 July < http://www. atimes.com/atimes/Southeast Asia/HG22Ae01.html>.

${ }^{82}$ Krismantari, Ika (2009) 'Bapepam probes Bumi Resource's auditors', The Jakarta Post, 31 January <http://www.thejakartapost.com/news/2009/01/31/bapepam-probes-bumi-resource\%E2\%80\%99sauditors.html $>$.

83 Jakarta Globe (2009) 'Bapepam's Bumi Probe a 'Charade,' Analyst Charges', 17 June < $\underline{\text { http:// }}$ www.thejakartaglobe.com/archive/bapepams-bumi-probe-a-charade-analyst-charges/>. 
targeted companies, PT Fajar Bumi Sakti, PT Pendopo Energy Batubara, PT Darma Henwa Tbk. The value of these three transactions was IDR 6,2 Trillion. Each transaction has a value, IDR 2.47 Trillion with PT Fajar Bumi Sakti, IDR 1,3 Trillion with PT Pendopo Energy Batubara, and IDR 2,4 Trillion with PT Darma Henwa, Tbk. ${ }^{84}$

There was a time sequence for each transaction. The acquisition transaction of PT Fajar Bumi Sakti, through its holding company, Leap Forward Finance Ltd was conducted on 26 December 2008 under the Share Purchase Agreement. The second acquisition transaction of PT Pendopo Energy Batubara, through its holding company, Pendopo Coal Ltd was conducted on 5 January 2008 under the Share Purchase Agreement. While the third transaction was conducted on 23 December 2008 through the holding company of PT Darma Henwa, Tbk, Goodrich Management Corp under the Share Purchase Agreement.

The law applied at that time was Bapepam LK Rule Number IX.E.2 which was enacted in the Decree of Head of Bapepam No. Kep-04/PM/2000 dated 20 February 2001 on the Material Transactional and Core Business Shifting (Bapepam Rule No. IX.E.2 2001). Based on the definition in this regulation, 'Material Transaction means any purchase, sale, or shares participation, and/ or any purchase, sale, transfer, exchange of assets or business segment with a total value equal or greater than one of following:

a. $10 \%$ of a company's revenue, or

b. $20 \%$ of a company's equity. ${ }^{\prime 5}$

If the transaction falls within the above definition, 'the Issuer and Public Companies must obtain approval from Shareholders General Meeting in accordance with procedures and requirements stipulated by the regulation no. IX.E.2 2001".86

At the time of the three transactions, 20\% of the revenue of PT Bumi Resources Tbk was about IDR 2,5 Trillion in 2007 and about IDR 3,7 Trillion in 2008. At the time $20 \%$ of the equity in 2007 were IDR 2,47 Trillion and in 2008 were about IDR 3,48 Trillion. ${ }^{87}$ If the above financial report was linked to the value of the three corporate actions by PT Bumi Resources Tbk then those three transactions fall within the definition of material transaction in Regulation No IX.E.2 2001.

However, if we refer to the definition in Regulation No IX.E.2 2001, the materiality of the transaction refers to "any purchase". The argument by the management of PT Bumi Resources Tbk was that those transactions were not in a series of transactions because they were conducted at different times, with different parties, and with different objects. Before the final investigation was finished, Bapepam LK and Indonesian Stock Exchange stated that those transactions were a series of transactions, thus falling within the definition in Regulation No. IX.E.2 2001.88

\footnotetext{
${ }^{84}$ Bumi Resources's Financial Report 2008.

85 Point 1Bapepam-LK Rule Number IX.E.2 2001.

${ }^{86}$ Point 2 Bapepam-LK Rule Number IX.E.2 2001.

87 Bumi Resources's Financial Report 2007 and 2008.

88 Bapepam LK stated opinion in several news that the deals in Bumi's transactions may be sub-
} 
There are also strong potential expropriation of public shareholders in these transactions because the prices of the transactions are far above their book value. While the company and its parent company, PT Bakrie \& Brothers is already heavily indebted, these transactions will also put further burden on the company. ${ }^{89}$

However, after the investigation, Bapepam-LK concluded that the acquisitions did not constitute a material transaction because those transactions took place in different fiscal years. ${ }^{90}$ The result then, PT Bumi Resources Tbk had been let off from the material transaction contravention. PT Bumi Resources Tbk benefited from the regulation loopholes to avoid an obligation to gain approval from the Shareholder General Meeting in accordance with procedures and requirements in capital markets regulations. In this case, Bapepam LK acknowledged the weakness of regulatory framework. As a result, in 2011, the Material Transaction regulation was being revised, ${ }^{91}$ changing the definition of material transaction from 'any transaction' to 'a series transactions'.

\section{B. PT Media Nusantara Citra Tbk case}

PT Media Nusantara Citra Tbk (MNC Group) is the biggest player in Indonesia media, particularly television. ${ }^{92}$ This group is controlled by Hary Tanoesoedibjo, a prominent businessman who recently joined the Political Party. ${ }^{93}$ In 2011, MNC Group was sued by one of its public shareholders in District Court of Central Jakarta. The object of the dispute is the allegation of misleading information in MNC Group prospectus when the company did the initial public offering in 2007.

The plaintiff sued the company on the basis that the company should have disclosed the dispute with its subsidiary company; PT TPI (now called MNC TV). The plaintiff argues that the dispute over PT TPI was a material fact because this subsidiary company gives $21 \%$ contribution of income to the MNC Group. ${ }^{94}$ Furthermore, the materiality of this information can be proven when the price of MNC Group's shares decreased due to the exposure of the dispute over the ownership of PT TPI since 2010. Thus, the plaintiff insisted that he suffered loss due to misleading information in MNC Group's prospectus. The rationale is that if the information about the dispute over the TPI ownership ${ }^{95}$ was published in prospectus, investors

stantial and material according to capital market regulation. See i.e, the Jakarta Post, 2009.

${ }^{89}$ Krimantari, Ika (2009) 'Stock Market: Bapepam to probe Bumi shopping spree', The Jakarta Post, 13 January <http://lgtv.thejakartapost.com/index.php/read/news/194993>.

90 Obor, Yohanes (2009) 'Bapepam-LK Says Bumi’s Acquisitions Appear Clean', The Jakarta Globe,

26 January <http://www.thejakartaglobe.com/archive/bapepam-lk-says-bumis-acquisitions-appearclean $/>$.

91 Bapepam-LK Rule Number IX.E.2 2011.

92 This group owns three of the country's largest television networks, RCTI, MNC TV and Global TV. Together, these three television networks control $37 \%$ of the national television audience. Besides television networks, MNC Group also owns a regional broadcasting network, Sindo which operates 21 regional TV stations and 16 radio stations. Other media networks owned by MNC Group are Seputar Indonesia, the daily national newspaper and news website, Okezone.

93 Infoasaid (2012) 'Indonesia Media and Telecoms Landscape Guide', Infoasaid, 30 November <http://www.infoasaid.org/sites/infoasaid.org/files/indonesia guide - final 271112 20.12.12.pdf>.

${ }_{94}$ Abdul Malik Jan v PT Media Nusantara Citra Tbk, dkk, Distric of Central Jakarta Court Decision, No 29/PDT.G/2011/PN.JKT.PST (21 June 2011).

${ }_{95}$ Basically, the background of the dispute over the ownership of PT TPI started when Harry Tanoe 
would have sufficient information for making investment decisions.

After the decision of the Supreme Court was released, the MNC Group share price dropped by $10.34 \%$. Following the price declines, the IDX temporarily suspended the stock's trading in order to avoid unfair trading. ${ }^{96}$ The IDX head of assessment for services companies has stated that the decision to suspend the MNC Group stock trading followed the Supreme Court's ruling on the TPI ownership dispute. $^{97}$

Although, it has been noted that there is a significant reform through more rigorous disclosure rules with focus on monitoring and enforcing of rules and regulations, this case depicts that the implementation of timely and reliable disclosure is either not necessary or desirable on the side of companies. The desire not to comply with disclosure regulations might derive from the typical ownership of many Indonesian companies which is heavily centralized, which leads to the mind-set that there is no incentive for being transparent.

The characteristic of most Indonesian companies such as concentrated ownership, pyramiding, structure of group companies and cross shareholdings might not motivates them to be transparent without any incentive. ${ }^{98}$ On the other hand, within the centralized ownership, the implementation of corporate governance, such as through compliance to disclosure procedures might be seen as a costly managerial exercise, which will not be appreciated by corporate managers and owners. ${ }^{99}$ It seems that Indonesian capital markets players still do not see the benefit of being transparent which would make it more attractive for companies to carry out Initial Public Offerings (IPOs) in Indonesia and for investors to put their capital in public listed companies. ${ }^{100}$

through PT Berkah Karya Utama lent TPI about US \$ 53 Million because at the time TPI was in debt after the 1998 crisis. At that time, TPI was owned by Siti Hardiyanti Rukmana (Tutut), former President Suharto's eldest daughter. As Hary lent TPI money, he insisted on the right to convert the debt into equity. Nowadays, MNC TV is controlled by MNC Group owned by Harry Tanoesodibjo who bought PT Berkah Karya Bersama. The conversion of debt into equity reduced her position from majority shareholder to owning only $25 \%$ percent of the TPI's total shares.

Tutut challenged the equity conversion process in a district court. In 2011, Tutut won the appeal but in 2012, the High court overturned the District Court's decision in favour of Hary Tanoe. This decision was then appealed by Tutut in the Supreme Court. The Supreme Court then granted Tutut's appeal against PT Berkah Karya Bersama. Although the dispute was between Tutut and PT Berkah karya Utama, this company is affiliated to Hary Tanoe. Furthermore, the object of the dispute was Berkah's ownership in MNC Group (previously TPI TV). MNC Group then acquired the 75\% shares in MNC Group.

Although, Hary Tanoe insisted that the dispute over the TPI ownership has no correlation with the MNC Group, the company that he controls, when the TPI shares were transferred from Siti Hardiyanti Rumana to PT Berkah Karya Bersama, the owner of PT Berkah Karya Utama was Hary Tanoe. The above information is extracted from The Jakarta Post, 2013; Bisnis.com, 2013; Indonesian IDX, 2013; Merdeka. com, 2013.

${ }^{96}$ Wibowo, Suryo (2013) 'IDX Suspends MNC Stocks', Tempo, 14 October <http://en.tempo.co/ read/news/2013/10/14/056521622/IDX-Suspends-MNC-Stocks>.

97 A statement from Umi Kulsum, IDX head of Assessment of Services Companies, cited in Wibowo, Suryo (2013) 'IDX Suspends MNC Stocks', Tempo.co, 14 October < $\underline{\text { http://en.tempo.co/read/ }}$ news/2013/10/14/056521622/IDX-Suspends-MNC-Stocks>.

${ }^{98}$ Wulandari, Etty R and Asheq R Rahman (2004) 'Political Patronage, Cross Holings and Corporate Governance in Indonesia', in Ferdinand A Gul and Judy S L Tsui, The Governance of East Asian CorporationsPost Asian Financial Crisis. Palgrave Macmillan, 93.

99 Ibid.

${ }^{100}$ (Organization for Economic Co-operation and Development, 2007) 


\section{PT Sumalindo Tbk case}

PT Sumalindo Tbk case also depicts the phenomenon of such Indonesian corporate characteristics which result in the discrimination of minority shareholder's right. PT Sumalindo Tbk owns more than $30 \%$ of Indonesian forest market. Moreover, PT Sumalindo Tbk is one of the top five wood distributors in the world. The annual report of PT Sumalindo Tbk in 2012 stated that PT Sumalindo Tbk owns more than 840 thousand hectares of nature forest and 73 thousand hectare of industrial plant forest. However in five years, PT Sumalindo Tbk never mentioned its profits in the financial report. ${ }^{101}$

To pursue his right, one of its minority shareholders, submitted a petition to the district court to ask for inspection of the company's books. The purpose of the inspection is to obtain information in the event of suspicion that the company has committed acts which break the capital markets Regulation Number IX.E.2 resulting in detriment to minority shareholders. In regards to this case, the district court of South Jakarta accepted the application. Although, this decision was appealed, on 12 September 2012, Supreme Court rejected the appeal from PT Sumalindo Tbk.

In this case, the ground of the expropriation of minority shareholders' rights derived from the corporate action conducted by the company in which PT Sumalindo bought the Zero Coupon Bond from its subsidiary company without paying a guarantee. Furthermore, this action was conducted before the approval of the GMS. PT Sumalindo Tbk also made a sales and purchase agreement with another subsidiary company to sell PT 60\% Sumalindo's shares without informing to the other shareholders in General and Extraordinary Meetings of Shareholders. ${ }^{102}$

PT Sumalindo Tbk case shows the difficulty in implementing corporate governance in Indonesian public listed companies due to the pyramid structures of group companies. This situation has been compounded by the lack of transparency and accountability. PT Sumalindo Tbk did not follow the corporate governance according to the Capital Market Regulations in relation to the material transaction mechanism. PT Sumalindo Tbk was supposed to obtain the approval from SGM and the bond purchase should have been put on the SGM agenda, including a specific session in the meeting to explain the reason of its purchase.

The characteristic of most Indonesian companies such as concentrated ownership, pyramiding, structure of group companies and cross shareholdings might not motivates them to be transparent without any incentive. ${ }^{103}$ On the other hand, within the centralized ownership, the implementation of corporate governance, such as through compliance to disclosure procedures might be seen as a costly managerial exercise, which will not be appreciated by corporate managers and owners. ${ }^{104}$ It seems that Indonesian capital markets players still do not see the benefit of being transparent which would make it more attractive for companies to

\footnotetext{
101 Almawadi, Issa (2012) 'Kasus Bumi tunjukkan kelemahan pengawasan bursa', Kontan, 17 Desember <http://investasi.kontan.co.id/news/kasus-bumi-tunjukkan-kelemahan-pengawasan-bursa>.

${ }_{102}$ PT Sumalindo Lestari Jaya Tbk v Deddy Hartawan Jamin dan Imani United Pte. Ltd , Decision of the Supreme Court No 3017 K/Pdt/2011 (12 September 2012).

103 Wulandari, Etty R and Asheq R Rahman, above n. 98, 93.

104 Ibid.
} 
carry out Initial Public Offerings (IPOs) in Indonesia and for investors to put their capital in public listed companies. ${ }^{105}$

This existing legal culture in the Indonesian capital market becomes an obstacle to the implementation of good corporate governance. The study suggested that the important aspect to support the implementation of transparency as part of corporate governance is legal culture. ${ }^{106}$ Without a high standard of self-discipline, integrity and ethical values from board and top management, the compliance even to the existing disclosure regulations might be difficult to be achieved. On the other side of regulation, the absence of disclosure of beneficiary ownership might also make more different the task to detect and observe opportunistic activities and abusive transactions by controlling owners, such as related party transactions, extract resources and asset from the company they control.

\section{IV.Improving Commitment to Detecting and Punishing Violations by Financial Supervisory Agency}

Besides the low compliance of corporate governance from the side of public listed companies, it is important to highlight the role of Financial Supervisory Agency and examine what has been done and should be done. Several critiques have been addressed to the role of Bapepam LK (now OJK) in handling the above cases. ${ }^{107}$

In Sumalindo Tbk case for example, although the expropriation of a minority shareholder in PT Sumalindo Tbk has been handled by the court through the right of a shareholder to pursue investigation by submission to a court, ${ }^{108} \mathrm{OJK}$ (former Bapepam LK) might take an action in this case, protecting shareholders' rights.

Based on Bapepam-LK Rule Number X.K.1 Concerning Disclosure of Information that must be made public immediately, PT Sumalindo has an obligation to report to Bapepam and make public any material information regarding events that may affect the price of securities or investor's decisions, not later than 2 (two) working days after the event occurs. ${ }^{109}$ Some of the information that needs to be disclosed is 'any important litigation against the company and/or the company's directors or commissioners.' ${ }^{110}$ The Supreme Court decision in this case must be evidence that there is litigation against the company that should be disclosed.

Basically, Bapepam-LK has power to 'inspect and investigate any person, issuers and Public Companies with respect to suspected violations of the Capital Market Law or its implementing regulation'. ${ }^{111}$ The question from this case that I

105 Organization for Economic CO-operation and Development (2007) 'Corporate Governance in Emerging Markets-Enforcement of Corporate Governance in Asia-The Unfinished Agenda', OECD Publishing.

${ }^{106}$ Benny Simon Tabalujan, 'Why Indonesian Corporate Governance Failed - Conjectures Concerning Legal Culture', (2002) Columbia Journal of Asia Law.

107 See i.e, Investor Daily Indonesia, 2012; Hukumonline, 2012.

108 Article 138 Law No 0 of 2007 Concerning Limited Liability Company.

${ }^{109}$ Bapepam-LK Rule Number X.K.1 Concerning Disclosure of Information that must be made Public Immediately, point 1.

${ }^{110}$ Bapepam-LK Rule Number X.K.1 Concerning Disclosure of Information that must be made Public Immediately, point $2 \mathrm{k}$.

111 Undang-Undang Republik Indonesia Nomor 8 Tahun 1995 Tentang Pasar Modal [Law of the 
would like to highlight is the extent the Capital Regulator should be involved in this case in order to protect the interest of investors and the public.

In Sumalindo Tbk case, Bapepam LK (now OJK) might get involved to secure the public interest in order to prove the legal soundness of Indonesian Capital Market. The purpose of the Capital Market Law is to provide a sound legal foundation for persons that do business in the Capital Market and of protecting the investing public against practices that may cause loss. Having stated that, Bapepam LK (now OJK) should be involved in this case to ensuring the protection of minority shareholders.

There has been a decision by the Supreme Court which ordered conducting an examination of a Company in relation to material transactions allegations. Regretfully, Bapepam-LK seems to be avoiding getting involved in investigating capital markets cases as long as investors have claimed loss. ${ }^{112}$ Although, there is not yet a report from the investors who claim loss to Financial Authority Services, a more pro-active approach needs to be used. Bapepam LK (now OJK) can investigate based on the Supreme Court decision. This can be used as an indication to start investigations. As noted in Government Regulation Number 46 of 1995 Concerning Investigation Mechanism in Capital Market Area, investigations can be done if there is indication of violations of the Capital Market Law and regulations. In this case, several news reports have published information in relation to this case. ${ }^{113}$

Based on the provisions mentioned, it is clear that the authority given to Bapepam is powerful. It covers the power to regulate, investigate and to sanction misconduct. While in financial market, the ultimate goal of regulation is minimalist intervention designed to correct market failure, ${ }^{114}$ I would argue that in the unfriendly legal protection environment for investors, such as the case in developing countries, the effectiveness of enforcement should be prioritised and maximised. This means, the more proactive approach from the authority to give effect to the substantive law is needed in order to raise investors' confidence in Indonesian capital markets. Due to its urgency, this priority should prevail over the skews of policy direction and regardless of budgetary priorities and operational capacity.

If we look at the enforcement framework of capital markets regulations, the regulatory objectives of the Capital Markets Law do not provide a clear roadmap towards an enforcement strategy. In addition, the authority given by the Law empowers Bapepam-LK with discretion in enforcing capital markets regulations. This indicates that enforcement is unlikely to be the response to every contravention.

In relation to that, the agency must put a priority to take on much more total and systematic risk-based approaches of regulatory initiatives, such as in the United Kingdom, the United States, Australia and Canada. ${ }^{115}$ In UK, the Financial

Republic of Indonesia Number 8 Year 1995 Concerning Capital Market] elucidation of art 5 [unofficial English trans].

112 William E Daniel, above n 4, 28

113 See i.e., Okezone, 2013; SindoNews, 2012; Kontan, 2012.

114 Tony Prosser, 'Regulation and Social Solidarity' (2006) 33 Journal of Law and Society 364 cited in Justin O’Brien, Private Equity, Corporate Governance and the Dinamics of Capital Market Regulation, (Imperal College Press, 2007) 9.

115 Bridget M Hutter, 'The Attractions of Risk-based regulation: accounting for the emergence of 
Services Authority has adopted a risk based approach, an approach which reflects a broad move in financial regulatory systems. ${ }^{116}$ Consequently, not all contraventions are necessarily the subject of enforcement action. On the other hand, specific priority areas may be targeted for action because of the implications they carry in terms of risk to the statutory objectives. However, the shortage of this approach is that some contraventions might be ignored or because of the low risk areas. ${ }^{117}$

In the case of Indonesia, as there is nothing in statutory framework that explicitly or implicitly requires the authority to adopt such an approach in enforcing the law, the outcome might be a policy choice made by Bapepam-LK. What is missing from the approach taken by Bapepam-LK is that, there is no clear risk-based tools to be used in measuring the overall risk posed to the authority's objectives, for instance, a mechanism that can score the risk against a number of probability and impact factors. This system is that which has been adopted by the FSA. ${ }^{.18}$

Having explored the reasons on the side of the financial regulatory system, the actions taken by Bapepam-LK might be understandable. Yet, since a system is only the tool, knowing the weaknesses of the regulatory mechanism should be a starting point to improve the system itself. Thus, without the willingness and a firm policy's direction, the attitude for blaming the authority for the weak enforcement might be continued.

\section{Conclusion and Recommendations}

While the regulatory reform in corporate governance along with capital market regulatory framework has continuously been conducted in response to the market dynamic, the enforcement of shareholders' protection is not yet perceived by the regulated entities to be as effective and desirable for regulatory credibility. The above three cases depict that financial transactions that discriminate against minorities result from loopholes in the law and weak enforcement of capital markets law.

Indeed, there has been improvement in enhancing the investor protection through regulations. Some revised regulations in relation to the issuer's obligations to obtain minority shareholders' approval and disclose material transactions have been made. However, with the concentrated structure of ownership, pyramiding structure of company and cross shareholdings, a further effort to enhance disclosure and enforcement of beneficial ownership need to be implemented by obligating the issuers to reveal beneficiary ownership.

On the other hand, a study on the Indonesian corporate governance behaviour concluded that the failure of corporate governance in Indonesian public listed companies is due to 'the neglected role of the legal culture in

risk ideas in regulation', (Discussion Paper No 33, Centre for the Analysis of Risk and Regulation, London School of Economics, 2005) 1.

${ }^{116}$ Article by Ian MacNeil, 'Enforcement of Capital Markets Regulation' compiled in Justin O'Brien, Private Equity, Corporate Governance and the Dinamics of Capital Market Regulation (Imperal College, Press 2007) 146.

117 Ibid 147.

118 Bridget M Hutter, above n 118, 6-7. 
corporate governance systems.'119 The apparent behaviour that is depicted from the above cases is that, there is tendency for corporate actors in Indonesia listed companies to avoid the obligation derives from law as long as it can bring benefit to their interest and this can be done safely.

As the aforementioned behaviour is exist in Indonesian corporate governance, it is necessary to incorporate a mechanism to improve Indonesian corporate governance with a measure to prevent that opportunistic behaviour which might led to the shareholders' expropriation. An alternative measure to improve the awareness of Indonesian public listed companies to the importance of good corporate governance, besides another hard law, is to introduce a mechanism which rates the performance of corporations based on their compliance to the corporate governance norms. This mechanism has been introduced in the ASEAN community. ${ }^{120}$ Though, it has not been enforced, through ASEAN scorecard, Indonesia can fully apply this mechanism to attract competition among public listed companies. Instead of formulating the ASEAN Scorecard through regulation, the publication of scoring based on corporate governance implementation might motivate companies to improve good corporate governance. The idea is to utilize the use of scoring as the credit rating agency does in rating debt securitization. Although it is not necessary as the debt securitization market relies on ratings, investors might use the scores on the corporate governance performance as investment parameters. By weighing the performance of corporate governance through a scoring mechanism, investors can choose whether they want to participate through shares in companies or not.

In addition, as a part of overall efforts to improve corporate governance standards and practice in Indonesian capital markets, strengthening law enforcement should be prioritized. Effective enforcement of the securities regulatory framework is critical to the supervision credibility. Importantly, it is identified by the market players as important to market confidence and development.

Since the Indonesian Financial Services Authority has a powerful authority to conduct surveillance, inspections, investigations, and punishing violations, the effectiveness of securities regulation enforcement depends on the supervisory agency in exercising its powers. The enhanced power given to Financial Services Authority requires a strong commitment to detecting and punishing violations which affect investor trust. Under an enhanced enforcement program, particularly for violations which concern breaches of mandatory, socially or ethically based behaviours, the supervisory agency might use penal enforcement for criminal violations. Besides, to give deterrent effect and in order to promote confidence, efforts should be made to ensure that the market community is sufficiently aware of all enforcement efforts. As substantive violations can take a long time to pursue through court, it should also be noted that the processes should also be supported by a supportive judicial system.

However, one should note that the primary function of s supervisory agency in this area is to contribute to the effectiveness of the economic system as a whole. Enforcing the law should not be interpreted as always implying the use of penal enforcement activities and sanctions. Yet, as the public perception that the enforcement in capital markets regulations is weak, transparency

119 Benny Simon Tabalujan, above n 87, 3.

120 The ASEAN, 'ASEAN Economic Community SCORECARD', (Charting Progress Toward Regional Economic Integration, the ASEAN Secretariat, 2012). 
might be reinforced by enforcement. Surely, there is need for consistency in enforcing the law, such as by adopting clear and consistent regulatory processes.

\section{Bibliography}

\section{A. Articles/Books/Reports}

Baxt, Robert, Ashley Black, and Pamela Hanrahan, Securities and Financial Services Law (Lexis Nexis Butterrworths, $8^{\text {th }}$ ed, 2012)

Daniel, William E, 'Corporate Governance in Indonesian Listed Companies - A Problem of Legal Transplant - Special Issue: Comparative Corporate Governance' (2003) 15 (1) Bond Law Review

Financial Sector Assessment Program, 'Indonesia: Implementation of the IOSCO Objectives and Principles of Securities Regulation' (IMF Country Report No 12/189, IMF, July 2012)

Financial Stability Board, 'Peer Review of Indonesia-Review Report' (FSB Report, 28 February 2014),

Hutter, Bridget $M$, 'The Attractions of Risk-based regulation: accounting for the emergence of risk ideas in regulation', (Discussion Paper No 33, Centre for the Analysis of Risk and Regulation, London School of Economics, 2005)

International Organization of Securities Commission, 'Objective and Principles of Securities Regulation' (June 2010)

IoD Big Picture, 'Bumi or bust - corporate governance implications of foreign issuers in London' (2013) IoD Big Picture

Isenmila, P A and Akinola Adewale, 'The Role of Capital Market in Emerging Company' (2012) 2 (6) International Journal of Business and Social Research 62.

Jurdant, Fianna, 'Disclosure of Beneficial Ownership and Control in Indonesia: Legislative and Regulatory Policy Option for Sustainable Capital Markets' (OECD Corporate Governance Working Papers No 9, OECD, 2013)

Komijani, Akbar and Habib Soheili Ahmadi,' Analysis of the Role of Protecting Shareholders Rights in Expanding Stock Market in a Selected Developing Countries' (2012) 3 (17) International Journal of Business and Social Science

Krisnamurti, Chandrasekhar, Aleksandar Sevic and Zeljo Sevic, 'Legal Environment, Firm-level Corporate Governance and Expropriation of Minority Shareholders in Asia' (2005) 38 Economic Change and Restructuring

MacNeil, Ian, 'Enforcement of Capital Markets Regulation' in Justin O'Brien, Private Equity, Corporate Governance and the Dinamics of Capital Market Regulation (Imperal College, Press 2007)

Makes, Yozua, 'Challenges and Opportunities for the Indonesian Securities Takeover Regulations: General Framework and Analysis from Dutch Law and Theoretical Perspectives' (2012) Makes International Law Journal

O'Brien, Justin, Private Equity, Corporate Governance and the Dynamics of Capital Market Regulation (Imperal College, Press 2007)

Organization for Economic CO-operation and Development (OECD), 'Corporate Governance in Emerging Markets-Enforcement of Corporate Governance in Asia-The Unfinished Agenda' (2007) OECD Publishing

Otoritas Jasa Keuangan, Statistik Pasar Modal, 30 September - 4 Oktober 2013 [Financial Services Authority Capital Market Statistic Report, September 30-October 4, 2013

Porta, Rafael la, Florencio Lopes-de-Silanes, Andrei Shleifer, and Robert Vishny, 'Corporate Ownership Around The World' (1999) 54 (2) The Journal of Finance 
Prosser, Tony, 'Regulation and Social Solidarity' (2006) 33 Journal of Law and Society 364 cited in Justin 0'Brien, Private Equity, Corporate Governance and the Dinamics of Capital Market Regulation, (Imperal College Press, 2007)

Tabalujan, Benny Simon, 'Why Indonesian Corporate Governance Failed - Conjectures Concerning Legal Culture' (2002) Revised Working Paper-Columbia Journal of Asia Law

Tabalujan, Benny S, Indonesian Company Law A Translation and Commentary, (Singapore: Sweet \& Maxwell Asia, 1997)

Technical Committee of the International Organization of Securities Commission, Principles for Periodic Disclosure by Listed Entities, Final Report (February 2010)

The ASEAN, 'ASEAN Economic Community SCORECARD', (Charting Progress Toward Regional Economic Integration, the ASEAN Secretariat, 2012)

Wulandari, Etty R and Asheq R Rahman, Political Patronage, Cross Holings and Corporate Governance in Indonesia, cited in Ferdinand A Gul and Judy S L Tsui, The Governance of East Asian Corporations-Post Asian Financial Crisis, (2004) Palgrave Macmillan

Zweigert, Konrad and hein Kotz, An Introduction to Comparative Law, (Oxford University Press, 1998) 4 cited in Yozua Makes, 'Challenges and Opportunities for the Indonesian Securities Takeover Regulations: General Framework and Analysis from Dutch Law and Theoretical Perspectives' (2012) Makes International Law Journal

\section{B. Cases}

Abdul Malik Jan v PT Media Nusantara Citra Tbk, dkk, Distric of Central Jakarta Court Decision, No 29/PDT.G/2011/PN.JKT.PST, 21 June 2011

PT Sumalindo Lestari Jaya Tbk $v$ Deddy Hartawan Jamin dan Imani United Pte. Ltd, Indonesian Supreme Court, No 3017 K/Pdt/2011,12 September 2012 reported in Direktori Putusan Mahkamah Agung Republik Indonesia

\section{Legislation}

Undang-Undang Republik Indonesia Nomor 40 Tahun 2007 Tentang Perseroan Terbatas [Law of the Republic of Indonesia Number 40 of 2007 Concerning Limited Liability Company] art 53(2) [unofficial English trans]

Undang-Undang Republik Indonesia Nomor 8 Tahun 1995 Tentang Pasar Modal [Law of the Republic of Indonesia Number 8 Year 1995 Concerning Capital Market] elucidation of art 3 [unofficial English trans]

Bapepam-LK Rule Number IX.E.1 Concerning Conflicts of Interest on Certain Transactions [Bapepam-LK trans]

Bapepam-LK Rule Number IX.E.2 Concerning Material Transactions and Change of Main Business Activities [Bapepam-LK trans]

Bapepam-LK Rule Number IX.F.1 Concerning Tender Offers [Bapepam-LK trans]

Bapepam-LK Rule Number III.C.7 Concerning Securities Sub Account With Central Securities Depository [Bapepam-LK trans]

Bapepam-LK Rule Number IX.H.1 Concerning Open Company Takeover [Bapepam-LK trans]

Bapepam-LK Rule Number X.K.1 Concerning Disclosure of Information that must be made Public Immediately [Bapepam-LK trans]

Bapepam-LK Rule Number X.K.2 Concerning Obligation to Submit Periodic Financial Statements [Bapepam-LK trans]

Bapepam-LK Rule Number X.K.6 Concerning Obligation to submit annual report for Issuers pr Public Companies [Bapepam-LK trans]

Bapepam-LK Rule Number X.M.1 Concerning Disclosure Requirements for Certain Shareholders [Bapepam-LK trans] 


\section{Other}

Agustia, Ririn, 'Rothschild Unhappy with Bumi Plc Deal', Tempo (online), 22 July 2013 $<$ http://en.tempo.co/read/news/2013/07/22/056498440/Rothschild-Unhappy-withBumi-Plc-Deal>

Almawadi, Issa, 'Kasus Bumi tunjukkan kelemahan pengawasan bursa', Kontan (online), 17 Desember 2012 <http://investasi.kontan.co.id/news/kasus-bumitunjukkan-kelemahan-pengawasan-bursa $>$

ASEAN Latin Business Forum 2012-Towards a Sustainable Future, Indonesia <http:// www.asean-latin2012.com/indonesia.html>

Banjarnahor, Donald, 'Sengketa TPI, Manajemen MNC TV Tidak Mau Ikut Campur', Bisnis.com (online), 19 October 2013 <http://m.bisnis.com/quick-news/ read/20131019/16/181830/sengketa-tpi-manajemen-mnctv-tidak-mau-ikutcampur>

Christina, Bernadette, Ananda Putri, Ismi Damayanti, Nafi, 'IDX Suspends MNC Stocks', Tempo.co (online), 14 October $2013<$ http://en.tempo.co/read/ news/2013/10/14/056521622/IDX-Suspends-MNC-Stocks>

Dewi Ramona, Sofiannew, Bonardo Maulana Wahono, Archie Ardian, 'Antaboga Mutual Funds Investigated', VivaNews (online), 3 December $2008<$ http://m.news.viva. co.id/news/read/13359-antaboga mutual funds investigated $>$

Dic, 'Supreme Court grants victory to Tutut over TPI dispute, The Jakarta Post (online), 10 October 2013 http://www.thejakartapost.com/news/2013/10/10/supreme-courtgrants-victory-tutut-over-tpi-dispute.html

Fathan Qorib, Andin Aditya Rahman, 'Facing AEC, OJK Prepares Banking Sector's Resilience Policy', hukumonline.com, 27 June 2014 http://en.hukumonline.com/ pages/lt5379bf7ed8ff2/facing-aec-ojk-prepares-banking-sector-s-resilience-policy

Fuad, Hafid, 'Masalah industry pasar modal RI minta dituntaskan', SindoNews. com (online), 17 December 2012 http://ekbis.sindonews.com/ $\mathrm{read} / 2012 / 12 / 17 / 32 / 698386 /$ masalah-industri-pasar-modal-ri-minta-dituntaskan

Global Business Guide Indonesia, Finance Capital Markets Overview (2012) <http:// www.gbgindonesia.com/en/finance/article/2011/capital_markets_overview.php $>$

Guerin, Bill, 'Politics and business mix in Indonesia', Asia Times (online), 22 July 2006 $<$ http://www.atimes.com/atimes/Southeast_Asia/HG22Ae01.html $>$

Herbert Smith, 'Indonesia-changes to Bapepam-LK material transaction rule (Part 2) and clarification on currency law requirement to use Rupiah for payments', e-bulletin, 20 December 2011 <http:/www.hbtlaw.com/uploads/ File/publications/20111220\%20\%20\%20Indonesia\%20\%20changes $\% 20$ to $\% 20$ BapepamLK\%20materialtransaction\%20rule.htm>

Hwa, 'Bapepam may wilt again, facing the big boys', The Jakarta Post (online), 24 January 2009 http://www.thejakartapost.com/news/2009/01/24/bapepam-maywilt-again-facing-big-boys.html

Indonesia-Investments, Market Capitalization of Indonesia's Stock Exchange Grows Strong (18 May 2013) < http://www.indonesia-investments.com/news/todaysheadlines/market-capitalization-of-indonesias-stock-exchange-grows-strong/ item745>

Indonesia-Investments, Finance <www.indonesia-investments.com/finance/item6 $>$

Infoasaid, 'Indonesia Media and Telecoms Landscape Guide' (Infoasaid, November 2012) $30<$ http://www.infoasaid.org/sites/infoasaid.org/files/indonesia guide final 271112 20.12.12.pdf>

Jakarta Globe, 'Bapepam's Bumi Probe a 'Charade,' Analyst Charges', Jakarta Globe (online), 17 June 2009 http://www.thejakartaglobe.com/archive/bapepams-bumiprobe-a-charade-analyst-charges/ 
Krismantari, Ika, 'Bapepam probes Bumi Resource's auditors', The Jakarta Post (online), 31 January $2009<$ http://www.thejakartapost.com/news/2009/01/31/ bapepam-probes-bumi-resource $\% \mathrm{E} 2 \% 80 \% 99$ s-auditors.html $>$

Krimantari, Ika, 'Stock Market: Bapepam to probe Bumi shopping spree', The Jakarta Post (online), 13 January 2009 <http://gtv.thejakartapost.com/index.php/ $\mathrm{read} / \mathrm{news} / 194993>$

Krismantari, Ika and Dicky Christanto, 'Sarijaya Named in Securities Scam' The Jakarta Post (online), 7 January 2009 <http://www.thejakartapost.com/news/2009/01/07/ sarijaya-named-securities-scam.html $>$

Kumar, Rashmi, 'Rothschild Demands Transparency In Bakrie Family Business', Campden FB (online), 11 November 2011 <http://www.campdenfb.com/article/ rothschild-demands-transparency-bakrie-family-business>

Mohamad, Ardyan, 'PT Berkah yang digugat Mbak Tutut bukan milik Hary Tanoe', Merdeka.com (online), 14 October 2013 <http://www.merdeka.com/uang/ptberkah-yang-digugat-mbak-tutut-bukan-milik-hary-tanoe.html>

Niken Widya Yunita, 'Tutut Rebut TPI dari Hary Tanoe', Detic.com (online), 11 October 2013 http://news.detik.com/read/2013/10/11/103244/2384330/10/10-perjalanantutut-rebut-kembali-tpi?n992204fksberita

Obor, Yohanes, 'Bapepam-LK Says Bumi's Acquisitions Appear Clean', The Jakarta Globe (online), 26 January 2009 <http:/www.thejakartaglobe.com/archive/ bapepam-lk-says-bumis-acquisitions-appear-clean/ $>$

Otoritas Jasa Keuangan, 'Struktur Organisasi OJK' < http://www.ojk.go.id/strukturorganisasi >

PT Media Nusantara Citra Tbk, 'Tanggapan atas Penghentian Sementara Perdagangan Efek PT Media Citra Tbk, PT. Global Mediacom Tbk dan PT. MNC Investama Tbk [A Response in relation to A Temporary Trading Suspend of the PT Media Citra Tbk, PT. Global Mediacom Tbk dan PT. MNC Investama Tbk' Stocks]' (Open Letter from PT Media Nusantara Citra Tbk TO Indonesian Stock Exchange No Ref. MNC/070-lgl/srt/x/13, 11 October 2013) <http://mnc.co.id/data/editor/ files/Surat $\% 20 \mathrm{MNCN} . \mathrm{PDF}>$.

Riseborough, Jesse, 'Vallar to Buy Bumi Minerals for \$2.1 Billion to Add Deposits', Bloomberg, 11 June 2011, <http://www.bloomberg.com/news/2011-06-10/ vallar-reports-reorganization-to-simplify-corporate-structure-.html>

Suryana, Dede, 'Sidang Gugatan Kasus SULI Ditunda', Okezone (online), 31 January $2013<$ http://news.okezone.com/read/2013/01/31/339/754813/sidang-gugatankasus-suli-ditunda>

Surwodjojo, Lubis Ganie, 'Bumi Says It's in the Clear Over Recent Acquisitions', LGSonline: News and Opportunities, 16 January 2009 <http://www.lgsonline. com/pages/g/lgsimp878/node/lgs4a1d77eb99e7a>

The Asian Development Bank, Strengthening Indonesia's Capital Market, Project Data Sheets Updated as of 31 March 2014 <http://www.adb.org/ projects/32507-032/details>

The Economist, 'Face Value: Indonesia's Teflon tycoon, Aburizal Bakrie has survived controversy in business and politics', The Economist (online-from the print edition), $14^{\text {th }}$ Jan $2010<$ http://www.economist.com/node/15278524>

The Telegraph, 'Bumi investigates alleged financial irregularities', The Telegraph, 24 September 2012 <http:/www.telegraph.co.uk/finance/newsbysector/industry/ mining/9562136/Bumi-investigates-alleged-financial-irregularities.html>

Wibowo, Suryo, 'IDX Suspends MNC Stocks', Tempo.co (online), 14 October 2013 $<$ http://en.tempo.co/read/news/2013/10/14/056521622/IDX-Suspends-MNCStocks $>$ 